\title{
DETERMINATION OF ENVIRONMENTAL, SOCIAL AND CORPORATE GOVERNANCE INDICATORS: FRAMEWORK IN THE MEASUREMENT OF SUSTAINABLE PERFORMANCE
}

\author{
Alena KOCMANOVÁ ${ }^{1}$, Iveta ŠIMBEROVÁ ${ }^{2}$ \\ ${ }^{1}$ Department of Economics, Faculty of Business and Management, Brno \\ University of Technology, Kolejni 4, 61300 Brno, Czech Republic \\ ${ }^{2}$ Department of Management, Faculty of Business and Management, Brno \\ University of Technology, Kolejni 4, 61300 Brno, Czech Republic \\ Email: ${ }^{1}$ kocmanova@fbm.vutbr.cz (corresponding author); \\ 2simberova@fbm.vutbr.cz
}

Received 14 December 2012; accepted 28 March 2013

\begin{abstract}
The article is concerned with determination of environmental, social and corporate governance (ESG) indicators of performance. The objective of carried-out empirical research is to determine ESG indicators as a key framework of the measurement of sustainable performance of a company in its Sustainable Reporting. On the basis of conducted empirical research, applying factor analysis, the environmental, social and corporate governance indicators for companies active in the processing industries CZ-NACE have been specified. The indicators were selected in a series of successive phases by a multi-factor analysis. The results of factor analysis indicated that the factors fall into three measurement categories: environmental (Investments, Emissions, Source Consumption, Waste), social (Society, Human Rights, Labour Practices and Decent Work, Product Responsibility), and corporate governance (Monitoring and Reporting, Corporate Governance Effectiveness, Corporate Governance Structure, Compliance). This article contributes to the effort to solve measurement of performance of the corporate sustainability and proposal to conceptual framework of ESG indicators of performance for the Sustainability Reporting of Czech companies operating in the processing industry.
\end{abstract}

Keywords: sustainable performance, environmental, social, corporate governance indicators, key performance indicators, empirical research, framework, Sustainability Reporting.

JEL Classification: G30, Q56, M14, G34, C38.

\section{Introduction}

Determination of environmental, social and corporate governance (ESG) indicators of performance is based on measurement of the situation specified by more factors at the same time. Defining suitable key indicators for the framework of measurement of the sustainable corporate performance that would support decision taking by the managers, investors and that would be reflected in the Sustainability Reporting is the very objective of 
determination of ESG indicators of performance at the corporate level. The research conducted by Kruse and Lundbergh (2010), Kocmanová et al. (2011), Kocmanová and Šimberová (2012) shows how important it is to incorporate the ESG indicators into the company strategy since financial indicators alone cannot provide an accurate picture of performance in its entirety. According to Greenwald (2007), who studies the development of ESG indicators intensely, as more investors include ESG factors into their decision-making, the inadequacy and inconsistency of much of the current reporting on these issues becomes ever clearer. It can be said that integration of ESG is now becoming an investment strategy.

Nonetheless, many international organizations do research and development work on key performance indicators, most notably Global Reporting Initiative (GRI 2011). The United Nations Conference on Trade and Development (UNCTAD/TDR 2008) released Guidelines for Indicators of Corporate Responsibility, which lists the indicators of environmental, social and corporate governance. The Chartered Financial Analyst (CFA) Institute issued a manual for investors, which include the environmental, social, and governance performance indicators (CFA 2012). The European Federation of Financial Analyst Societies (EFFAS 2008) established ESG performance indicators for its industry. Likewise, International Federation of Accountants (IFAC 2012) created a scorecard for benchmarks and key indicators of performance in the ESG areas. Another important software tool is ASSET4, which serves to determine the ESG performance of companies (Ribando, Bonne 2010).

For determining of ESG performance indicators effectively, it is essential to identify the appropriate key performance indicators (KPI). The KPI for ESG should meet certain requirements: significance, measurability, comparability, reliability, usefulness, easy to track, and highly expressive (EFFAS 2008) articulated the criteria for useable KPIs for ESG. Usually, the environmental, economic and social corporate data and information are being monitored, codified, registered and aggregated into KPIs (Bassen, Kovacs 2008; Garz et al. 2009).

Moreover, the process of defining, selection and measurement by non-financial indicators creates the added value, thus providing a broader view of sustainability. Linking objectives of non-financial indicators with the utmost financial goals of the company should contribute materially to reach of the long-time sustainable performance and to the Sustainability Reporting. Sustainability Reporting tools, such as ESG performance indicators, currently appear to be essential and they can lead to a Sustainably Successful state. In this context above all with the increasing demands of investors for the objective data about company activities, there is also a need to establish standards for publishing reports. An international organization Global Reporting Initiative (GRI) proposed in 2013 to GRI's fourth generation of Sustainability Reporting Guidelines G4 (GRI 2013). The current pressure on integrating financial and nonfinancial results of the company's activities into a single Integrated reporting could also include tne ESG performance indicators (Busco et al. 2013; Loska 2013).

Sustainability Reporting in the modern conception has been discovered by the companies in the Czech Republic with a great delay only, namely in connection with submitting optional environmental reports, social responsibility and business ethics released to the interested parties. Search for a correct approach for releasing the sustainability reports has not been defined in more specific terms yet in the companies of the Czech 
Republic, which fact is connected closely with determination of the key ESG indicators of performance that could contribute.

\section{Conceptual and theoretical analysis}

With respect to determination of the key ESG indicators of performance it is at first necessary to define performance and the key indicators of performance. Can performance of a company be defined unambiguously? It is in principle impossible to find an explicit definition, because performance of the company can be measured by different methods, more or less complex that can include theoretical and mathematic models. Neely et al. 1995) define corporate performance as the process of quantifying the efficiency and the effectiveness of activities; a set of measures combined to assess the performance of an organization as a whole. After further research Neely and Kennerley (2003), and Neely and Adams (2001) broadened this definition to a system of measuring the performance of a set of indicators used to quantify the efficiency and effectiveness of activities and of the supporting infrastructure, which facilitates obtaining, verifying, organizing, analysing, interpreting, and expanding the indicator data. Performance goes hand-in-hand with management driven by the so-called KPIs, both financial and non-financial. How many indicators should a company have to get a true picture of its performance? Kaplan and Norton (1996) recommend the maximum of 20 key indicators; Hope and Fraser (2003) suggest less than 10 key performance benchmarks. Parmenter (2007) came up with the rule of $10 / 80 / 10$, meaning that a company should have 10 key result indicators, up to 80 performance indicators, and 10 key performance indicators. A comprehensive performance measurement is fairly problematic since much of the evaluation is highly subjective. However, certain methods to establish the level of companies, industries, or countries do exist. Corporate management needs to make a significant effort to persuade investors to stay loyal, to demonstrate that companies are able to generate enough cash flow for self-financing, and that the balance sheet is strong enough to ride out a potential downturn in global economy. Authors Ginevičius and Vaitkūnaite (2006) research multidimensional nature of the organisational culture. When investigating its influence on access only performance influencing dimensions must be under consideration. The authors suggest the ways for reducing their number: content analysis and hierarchical structuring method.

\subsection{Environmental performance, social performance, corporate governance performance}

Czech Republic follows standards ISO 14000 and the underlying standard ISO 14001. Within the European Union, the Czech Republic holds the 11th place in EMAS, from the total of 4.5 thousand registered organizations. However, it is still on the top rung among the new member states in the number of registrations. In 2012, 27 organizations were registered in the Czech Republic with the EMAS program. Companies are now aware that investors consider in their decisions if the company tracks important environmental issues, if it is interested in the environmental impact of its activities and its environmental performance (Bansal 2005; Sharma, Henriques 2005), i.e. in the extent to which the company's economic 
activities are environmentally sustainable (Hart 1995). A few studies have recently explored the influence of corporate governance mechanisms on the company's environmental performance, such as Berrone and Gomez-Mejia (2009), Russo and Harrison (2005).

For social performance, it is necessary to determine the standards or guidelines that will be used in selecting the requisite indicators. Among those that address social issues are: Corporate Social Responsibility, Social Accountability 8000, ISO 26000, and Socially Responsible Investment. ISO 26000 stresses the importance of reporting on social responsibility performance to stakeholders (employees, local communities, investors and regulators) in accordance with the environmental, social and economic performance (Jacobsen 2011; Frost 2010). Social aspects of sustainable development at the corporate level represent a wide range of issues. Global Reporting Initiative considers social performance to be part of sustainable performance, along with economic and environmental performance. GRI does not define social performance, but it mentions the areas in a company that characterize it (Spirig 2006).

An important text that discusses the impact of administration and management in a company was authored by Berle and Means (1933), who analyse the impact of corporations and their managers not only on the company but on the society as a whole. Authors Monks and Minow (2011) focused on the role and structure of Board of Directors and supervisory councils in corporations. Corporate governance (CG), according to Baker and Anderson (2010) examines the ways how corporations are managed, administered and controlled. Authors Demb and Neubauer (1992) have this to say on the subject: it is the process thanks to which corporations responds to the rights and wishes of interested parties. Prominent authors Gourevitch and Shinn (2005) offer the following definition of CG: "The structure of authorities in the firm; that what lies at the heart of the most important problems in the company", such as who is entitled to the company's cash flow, who can influence its strategy and exploit its resources. It affects social mobility, stability and fluidity.

The determination of ESG performance indicators for companies from processing industries drew on international sources that feature performance indicators, namely GRI 2006, GRI 2011, GRI 2013, EMAS III, IFAC 2012, ISO 26 000, CSR, OECD Principles of Corporate Governance 2004, Green Paper on the EU Corporate Governance Framework 2011.

\section{Research methodology}

The selection of ESG performance indicators in this empirical research was done in a series of successive phases. The first phase of the research included the method of primary selection of the ESG indicators of performance, based on the international sources and deep interviews with experts of manufacturing companies in the Czech Republic. A questionnaire has been drafted, based on this critical research and interviews with experts (corporate director, EMS manager, CSR manager, HR manager, economist) of the selected companies of the manufacturing industry (with the introduced ISO 14001 standard and implemented social responsibility). The questionnaire has been broken down in to $4 \mathrm{sec}-$ tors: the first sector has been designed so to obtain the data from the TOP and medium level management respondents: $56.0 \%$ were represented by the TOP management, $44 \%$ - by 
the respondents corresponding to the status of medium level managers. The second to fourth sectors of questionnaires contain the questions focused on environmental aspects, social responsibility of the company and on corporate governance principles. Respondents were asked to mark their answers on a four-point Likert-type scale: $1=$ no, $2=$ definitely no, 3 = definitely yes, 4 = yes. The research was running in the period 2011 and 2012 in the companies of the manufacturing industry by personal visiting the companies. Companies of the manufacturing industry have been chosen from the database of Czech Environmental Information Agency of the Ministry of the Environment (CENIA), with introduced ISO 14001 standard and with more than 250 employees. The CENIA database accommodates in total 96 companies of the manufacturing industry with the introduced ISO 14001 standards. We have gathered data of 79 companies. These data have been prepared for empiric research. All calculations were analysed by the SPSS program for Windows, version 21, using a combination of different statistical methods, and factor analyses.

The methods of multi-dimensional analysis have been applied in the second phase to the set of indicators - objective and subjective ones. To identify the dominant factors affecting the company performance, the research utilized the Principal Component Analysis (PCA) method with VARIMAX rotation (minimizing the number of factors); data suitability was tested with Bartlett's Test of Sphericity which yielded values below $\mathrm{P}<0.05$. The Kaiser-Meyer-Olkin Measure of Sampling Adequacy (KMO), which has a recommended minimum value of 0.6 for factor analysis, was also applied (Sharma, Henriques 2005). The factor analysis was applied to reduce the set of ESG performance indicators.

\subsection{Environmental indicators}

From the examined set of 16 environmental indicators, indicator $11 \mathrm{n}$ Transportation was deleted for low correlation, so that 15 items entered the analysis. The results of Bartlett and $\mathrm{KMO}$ tests confirmed that the data is suitable for factor analysis $(\mathrm{KMO}=0.731$; Bartlett $=$ 411.055 , Sig $=0.000)$. It showed that the internal coherence of the data is appropriate. Using the PCA method, 4 factors were extracted: Investments and non-investment expenditures, Emissions, Source Consumption, Waste (Table 2). The results obtained from the factor analysis showed that the five referenced factors explained $70.59 \%$ of variation in the extension content for supporting ESG performance in manufacturing companies (Table 1).

\subsection{Social indicators}

From the monitored set of 19 social indicators, the following were deleted: 14 a Number of employees, 14d Number of work accidents, 14s Compliance with product laws and regulations, 14t Product safety and quality, because they exhibited very low variability, so that 15 items entered the analysis. The results of Bartlett and KMO tests confirmed that the data was suitable for factor analysis $(\mathrm{KMO}=0.715$; Bartlett $=353.618$; $\mathrm{Sig}=0.000)$. It showed that the internal coherence of the data is appropriate. By means of the PCA method, 4 factors were extracted: Society, Human rights, Labour Practices and Decent Work and Product responsibility (Table 4). The results obtained from the factor analysis showed that the 4 mentioned factors explained $62.673 \%$ of variation in the extension content for supporting ESG performance in manufacturing companies (Table 3). 
Table 1. Percent of variance explained by factors underlying the extension contents

\begin{tabular}{lcc}
\hline Factors & \multicolumn{2}{c}{ Extraction sums of squared loadings } \\
\hline $\begin{array}{l}\text { Investments and non-investment } \\
\text { expenditures for environmental } \\
\text { protection }\end{array}$ & \% of variance & Cumulative \% \\
\hline Emissions & 34.312 & 34.312 \\
\hline Source consumption & 11.237 & 45.548 \\
\hline Waste & 9.888 & 55.436 \\
\hline Laws and standards & 8.120 & 63.556 \\
\hline
\end{tabular}

Table 2. Rotated component matrix for the extension contents

\begin{tabular}{|c|c|c|c|c|c|c|}
\hline & & \multicolumn{5}{|c|}{ Factor loadings for components } \\
\hline & Content of extension & $\begin{array}{l}\text { Investments and } \\
\text { non-investment } \\
\text { expenditures }\end{array}$ & Emissions & $\begin{array}{c}\text { Source } \\
\text { consumption }\end{array}$ & Waste & $\begin{array}{l}\text { Laws and } \\
\text { standards* }\end{array}$ \\
\hline 110 & $\begin{array}{l}\text { Investments for } \\
\text { environmental protection }\end{array}$ & 0.778 & & & & 0.388 \\
\hline $11 \mathrm{p}$ & $\begin{array}{l}\text { Environmental non- } \\
\text { investment expenditures }\end{array}$ & 0.777 & & & & 0.431 \\
\hline $11 \mathrm{k}$ & Products and services & 0.568 & 0.436 & & & \\
\hline $11 \mathrm{e}$ & $\begin{array}{l}\text { Total quantity of released } \\
\text { water }\end{array}$ & 0.536 & & & 0.433 & \\
\hline $11 \mathrm{~d}$ & Biodiversity & 0.528 & & & & \\
\hline $11 \mathrm{~g}$ & $\begin{array}{l}\text { Emission of ozone- } \\
\text { depleting substances }\end{array}$ & 0.378 & 0.778 & & & \\
\hline $11 \mathrm{f}$ & $\begin{array}{l}\text { Total emission of } \\
\text { glasshouse gasses }\end{array}$ & & 0.741 & & & 0.308 \\
\hline $11 \mathrm{~h}$ & $\mathrm{NO}_{\mathrm{x}}, \mathrm{SO}_{\mathrm{x}}$ & & 0.714 & & & \\
\hline $11 b$ & Energy consumption & & & 0.884 & & \\
\hline $11 \mathrm{a}$ & Materials & & & 0.845 & & \\
\hline $11 \mathrm{c}$ & Water & 0.468 & & 0.610 & 0.343 & \\
\hline $11 \mathrm{i}$ & Dangerous waste & & & & 0.833 & \\
\hline $11 \mathrm{j}$ & Total quantity of waste & & & & 0.792 & \\
\hline 111 & Compliance & & & & & 0.773 \\
\hline $11 \mathrm{~m}$ & Fines and sanctions & & & & 0.334 & 0.768 \\
\hline & Cronbach's alfa & 0.959 & 0.777 & 0.749 & 0.678 & 0.371 \\
\hline
\end{tabular}

Notes: Factor loading $<0.5$ were omitted.

*Complementary indicators. 
Table 3. Percent of explained variance by factors underling extension contents

\begin{tabular}{lcc}
\hline Factors & \multicolumn{2}{c}{ Extraction sums of squared loadings } \\
\hline & $\%$ of variance & Cumulative $\%$ \\
\hline Society & 32.303 & $32 ., 303$ \\
\hline Human rights & 11.933 & 44.237 \\
\hline $\begin{array}{l}\text { Labour practices and decent } \\
\text { work }\end{array}$ & 10.247 & 54.483 \\
\hline Product responsibility & 8.190 & 62.673 \\
\hline
\end{tabular}

Table 4. Rotated component matrix for the extension contents

\begin{tabular}{|c|c|c|c|c|c|}
\hline & \multirow[b]{2}{*}{ Content of extension } & \multicolumn{4}{|c|}{ Factor loadings for components } \\
\hline & & Society & $\begin{array}{l}\text { Human } \\
\text { rights }\end{array}$ & $\begin{array}{l}\text { Labour practices } \\
\text { and decent work }\end{array}$ & $\begin{array}{c}\text { Product } \\
\text { responsibility }\end{array}$ \\
\hline $14 n$ & Community & 0.816 & 0.347 & & \\
\hline $14 \mathrm{~m}$ & $\begin{array}{l}\text { Contributions to } \\
\text { communities }\end{array}$ & 0.780 & & & 0.312 \\
\hline 141 & Child labor* & 0.753 & & & \\
\hline 140 & Active in politics & 0.685 & & & \\
\hline $14 \mathrm{p}$ & $\begin{array}{l}\text { Customer safety and } \\
\text { health protection }\end{array}$ & 0.498 & & & \\
\hline $14 \mathrm{i}$ & Discrimination & & 0.795 & & \\
\hline $14 \mathrm{~h}$ & Human rights & & 0.789 & & \\
\hline $14 \mathrm{~g}$ & Equal opportunity & & 0.637 & & \\
\hline $14 \mathrm{j}$ & $\begin{array}{l}\text { Freedom to associate and } \\
\text { collective bargaining* }\end{array}$ & & 0.525 & & 0.359 \\
\hline $14 \mathrm{e}$ & $\begin{array}{l}\text { Occupational diseases, } \\
\text { number of deaths }\end{array}$ & & & 0.760 & \\
\hline $14 \mathrm{~b}$ & Employee turnover rate & & & 0.717 & \\
\hline $14 \mathrm{c}$ & Working relations & & & 0.708 & \\
\hline $14 \mathrm{f}$ & Education and training & & & 0.600 & 0.549 \\
\hline $14 \mathrm{r}$ & $\begin{array}{l}\text { Marketing } \\
\text { communication }\end{array}$ & & & & 0.723 \\
\hline \multirow[t]{2}{*}{$14 q$} & Labeling of products & & & & 0.680 \\
\hline & Cronbach's alfa & 0.800 & 0.810 & 0.690 & 0.590 \\
\hline
\end{tabular}

Notes: Factor loading $<0.5$ were omitted.

$* 141$ and $14 \mathrm{j}$ were deleted because of legislation. 


\subsection{Corporate governance indicators}

From the monitored set of 19 social indicators, indicator 31e Vision and strategy was deleted because of low correlation, so that 18 items entered the analysis. The results of Bartlett and KMO tests confirmed that the data were suitable for factor analysis $(\mathrm{KMO}=642$; Bartlett $=424.356, \mathrm{Sig}=0.000)$. It showed that the internal coherence of the data is appropriate. By means of PCA, 4 factors were extracted: Monitoring and reporting, Corporate Governance Effectiveness, Corporate Governance Structure and Compliance (Table 6). The factor analysis results showed that the five referenced factors explained $55.391 \%$ of variation in extension content for supporting ESG performance in manufacturing companies (Table 5).

Table 5. Percent of explained variance by factors underlying extension contents

\begin{tabular}{lcc}
\hline Factors & \multicolumn{2}{c}{ Extraction sums of squared loadings } \\
\hline & \% of variance & Cumulative \% \\
\hline Monitoring and reporting & 25.596 & 25.596 \\
\hline CG effectiveness & 11.552 & 37.148 \\
\hline CG structure & 9.593 & 46.741 \\
\hline Compliance & 8.650 & 55.391 \\
\hline
\end{tabular}

\section{Results and discussions}

The ESG indicators of performance for the companies in manufacturing industry CZ-NACE have been determined on the basis of the performed empiric research by applying the factor analysis. These proposed ESG indicators could declare the level of sustainable performance of the company and create the basic framework for design of the Sustainability Reporting of the manufacturing industry companies in the Czech Republic. This article contributes to the efforts to deal with measurements of performance of the corporate sustainability and design of conceptual framework of the ESG indicators of performance for Sustainability Reporting of the Czech manufacturing industry companies. It is quite evident that the factors have been identified themselves with the preceding research and are linked by three measurable sectors represented by environmental, social and corporate governance indicators of performance. This way designed key ESG indicators of performance correspond with ESG indicators defined by Greenwald (2007), who has also determined sustainability performance of the companies by applying the tool ASSET4. Further on, the authors Singh et al. (2007) suggest that measurements of performance in link with environmental, social, economic and also technical aspects, the Organizational Governance, can become the method how to utilize and improve the corporate performance and determine the Composite Sustainability Performance Index.

It follows from our research that the Czech companies have been identified themselves with the environmental indicators defined in GRI. This is why the majority of the companies exerts every effort to reduce environmental impacts (after introduction of the 
Table 6. Rotated component matrix for the extension contents

\begin{tabular}{|c|c|c|c|c|c|}
\hline & \multirow[b]{2}{*}{ Content of extension } & \multicolumn{4}{|c|}{ Factor loadings for components } \\
\hline & & $\begin{array}{l}\text { Monitoring } \\
\text { and reporting }\end{array}$ & $\begin{array}{c}\mathrm{CG} \\
\text { effectiveness }\end{array}$ & $\begin{array}{c}\mathrm{CG} \\
\text { structure }\end{array}$ & Compliance \\
\hline $25 \mathrm{~d}$ & Inform about audit activities & 0.793 & 0.323 & & \\
\hline $25 \mathrm{a}$ & Inform about company goals & 0.761 & & & \\
\hline $25 \mathrm{c}$ & $\begin{array}{l}\text { Inform about changes } \\
\text { of ownership }\end{array}$ & 0.758 & & & \\
\hline $25 b$ & Inform about financial results & 0.745 & 0.310 & & \\
\hline $31 \mathrm{a}$ & CG structure & 0.519 & & 0.459 & \\
\hline $24 \mathrm{a}$ & Defend activities & 0.315 & 0.822 & & \\
\hline $24 b$ & Present collective report & & 0.743 & & \\
\hline $24 c$ & Present a specific action report & & 0.646 & 0.312 & \\
\hline $30 \mathrm{a}$ & Ethical conduct & & 0.627 & & \\
\hline $23 e$ & $\begin{array}{l}\text { Appointment of TOP } \\
\text { management }\end{array}$ & -0.340 & 0.396 & & \\
\hline $31 \mathrm{c}$ & Remuneration of $\mathrm{CG}$ & & & 0.798 & \\
\hline $31 b$ & CG and TOP management & 0.472 & & 0.535 & 0.373 \\
\hline $23 d$ & Reporting management & & & 0.513 & \\
\hline $31 \mathrm{~g}$ & $\begin{array}{l}\text { Equal opportunity: } \\
\text { women/men ratio in CG }\end{array}$ & & & 0.498 & \\
\hline $31 d$ & Stockholders rights & 0.431 & & 0.473 & \\
\hline $31 \mathrm{i}$ & Court decision & & & & 0.842 \\
\hline $31 \mathrm{f}$ & Corruption & & & & 0.708 \\
\hline $31 \mathrm{j}$ & Conflict of interest & & & & 0.610 \\
\hline & Cronbach's alfa & 0.959 & 0.777 & 0.749 & 0.678 \\
\hline
\end{tabular}

Note: Factor loading $<0.5$ were omitted.

ISO 14001 standard) stating that by reducing impacts of their companies on the environment they have reached a higher competitiveness. The ISO 14001 standard has also the positive effect that the companies monitor environmental indicators of performance much more thoroughly. The social indicators of the Czech companies have been identified with the GRI only partially, but even these designed indicators are related to the implemented social responsibility. Relation to social responsibility is linked explicitly with optional reporting in the social sector. The companies publishing reports in the social sector at the same time enter into its social responsibility in more social fields and also monitor more social indicators of performance. The Corporate governance indicators are not defined separately in the GRI, but certain indicators are defined within the framework of social and economic indicators of performance. Our research has resulted 
in the fact that the corporate governance indicators are connected very closely in the Czech Companies with behaviour of the company.

Framework of ESG indicators of performance of manufacturing industry companies is the following: the key environmental performance indicators were established for 4 measurement areas, which contain 11 environmental performance indicators, the key social performance indicators for 4 measurement areas, including 10 social performance indicators, the key corporate governance performance indicators for 4 measurement areas, with 8 corporate governance performance indicators (Table 7).

Stakeholder identification has shown to be particular relevant in the phase 2 of the proposed framework. Not only a such approach necessary for the application of any sustainability indicators performance, it is also consistent with modem stakeholder theory (IFAC, EFFAS). Moreover, utilization of the factor analysis for determination of the key indicators of performance is consistent with the authors (Ommani 2011; Hosseini et al. 2010; Petrosyan 2010), who have applied them for determination of the composite sustainable indicator. Multivariate data analysis techniques, which were found useful in the design or analysis of composite indicators, are also described. For further details, refer for example to Hair et al. (2006), Saisana et al. (2005), Vermunt (2008), Vermunt and Magidson (2005).

\section{Conclusions}

The article deals with the framework for measurements of sustainable performance determined by the ESG indicators of performance as the tool for the Sustainability Reporting. A critical literature search has revealed that little attention is paid to the quantitative and qualitative indicators that at the same time integrate ESG indicators of performance. We can therefore state that by integrating the ESG indicators of performance in the companies the most advantageous investment strategies can be reached, because the ESG indicators are focused on the long-time risks and opportunities linked with strategies of the companies where investment are performed. The ESG indicators of performance become the tool of the future cash flows, because the investors intend to reach above all excellent financial yields at the present risk levels, which is connected closely with the Sustainability Reporting. The emphasis is transferred little by little from the financial information towards the integrated approach, where all types of the relevant information for assessment and evaluation of corporate quality is complex. The Sustainability Reporting that would measure the sustainable profit as one of the complex triple-bottom-line becomes the current paradigm. Assessment and measurement of corporate performance is usually understood a typical feature of the majority of successful companies. Correct and timely decision taking is the basis for maintaining viability and development of the company. The data concerning performance of the company are the inevitable prerequisite for high-quality decision-making process. Monitoring of sustainable performance enables to assess consequence, quality, timing and impact of the taken decision(s) on normal functioning of the company. The company NWR, releasing the environmental, social and economic indicators of performance in its Sustainable Development Report in 2001 (in conformity with GRI (2011)), can serve as an example in the Czech Republic. 


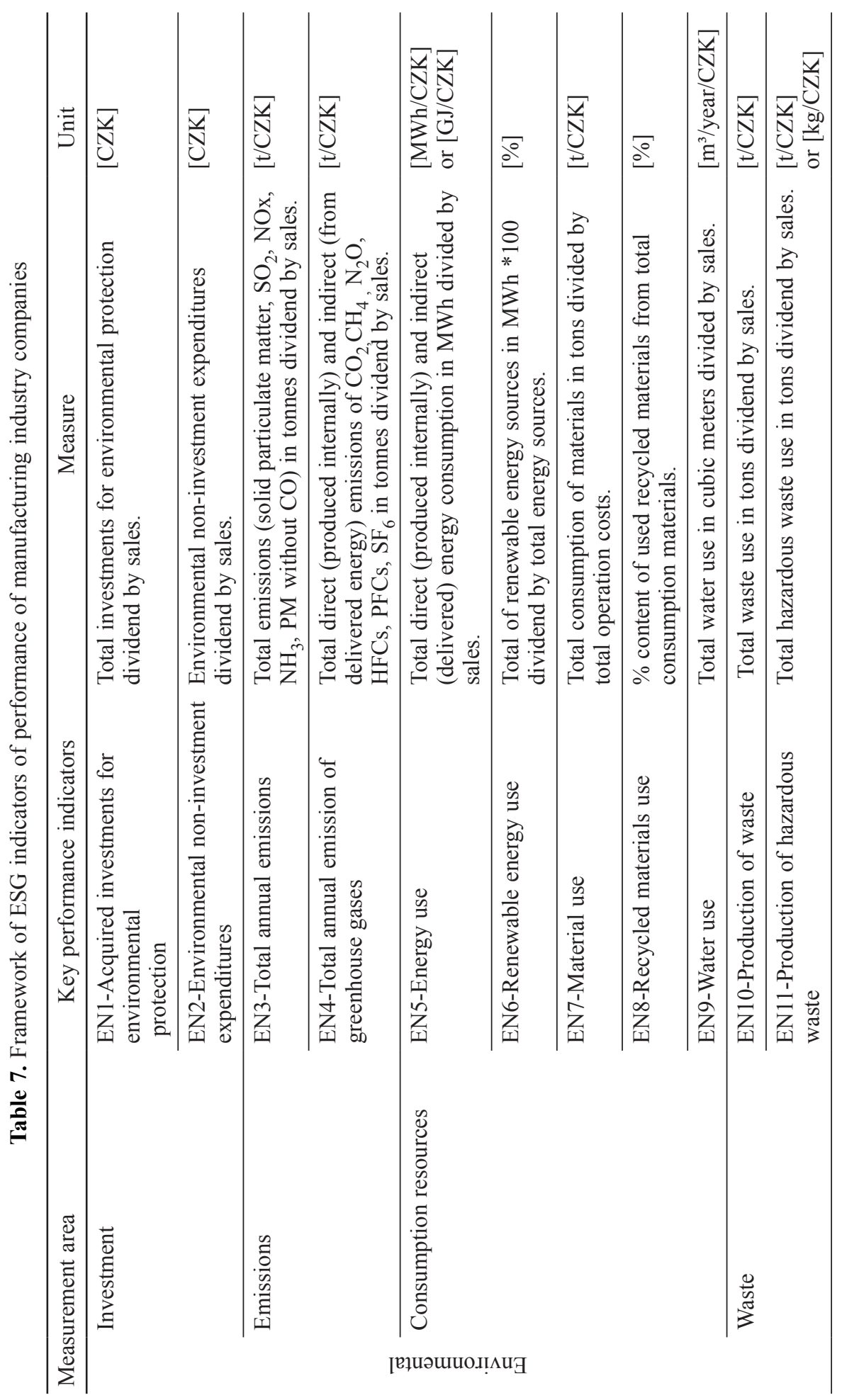




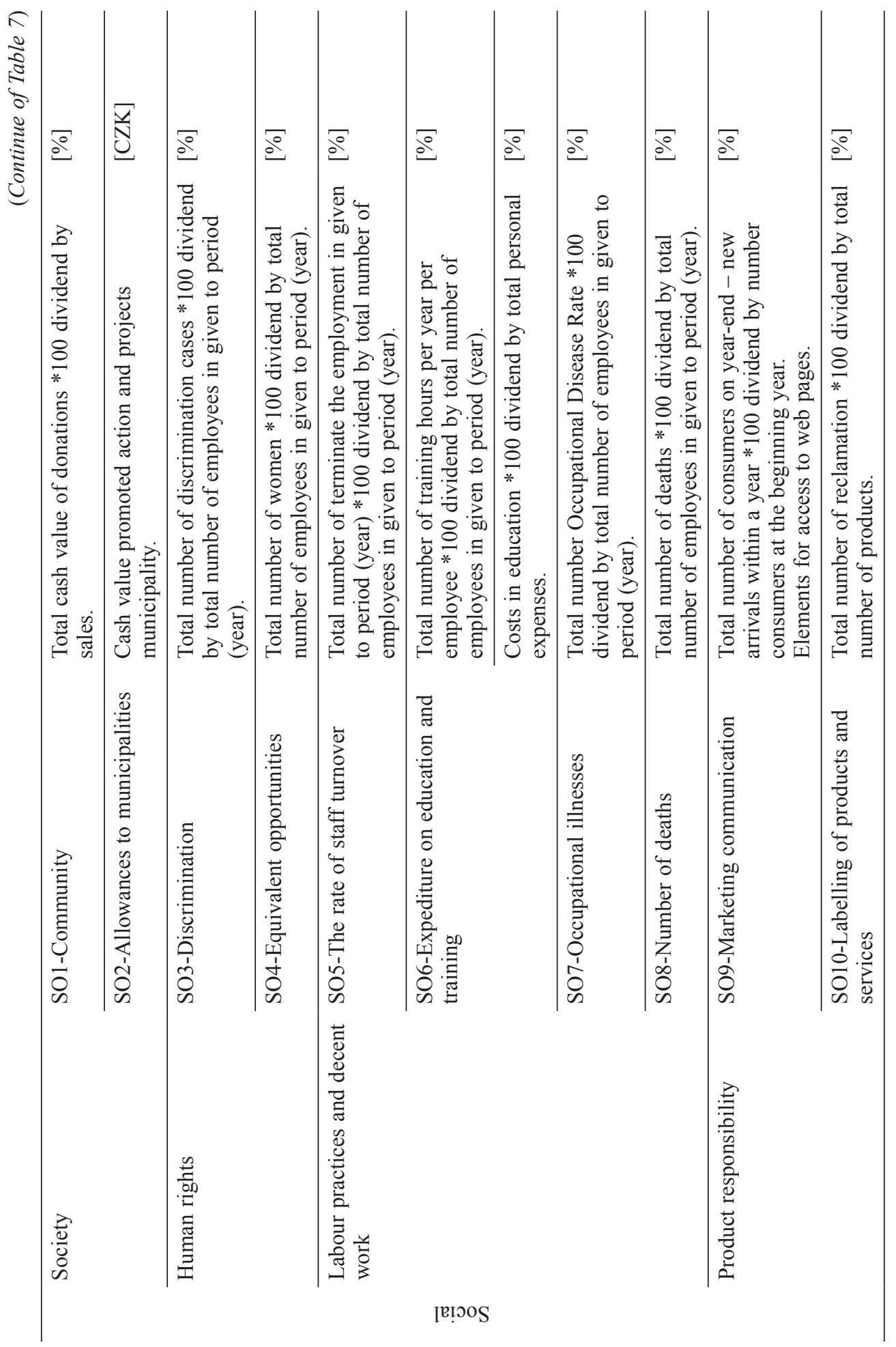




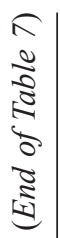

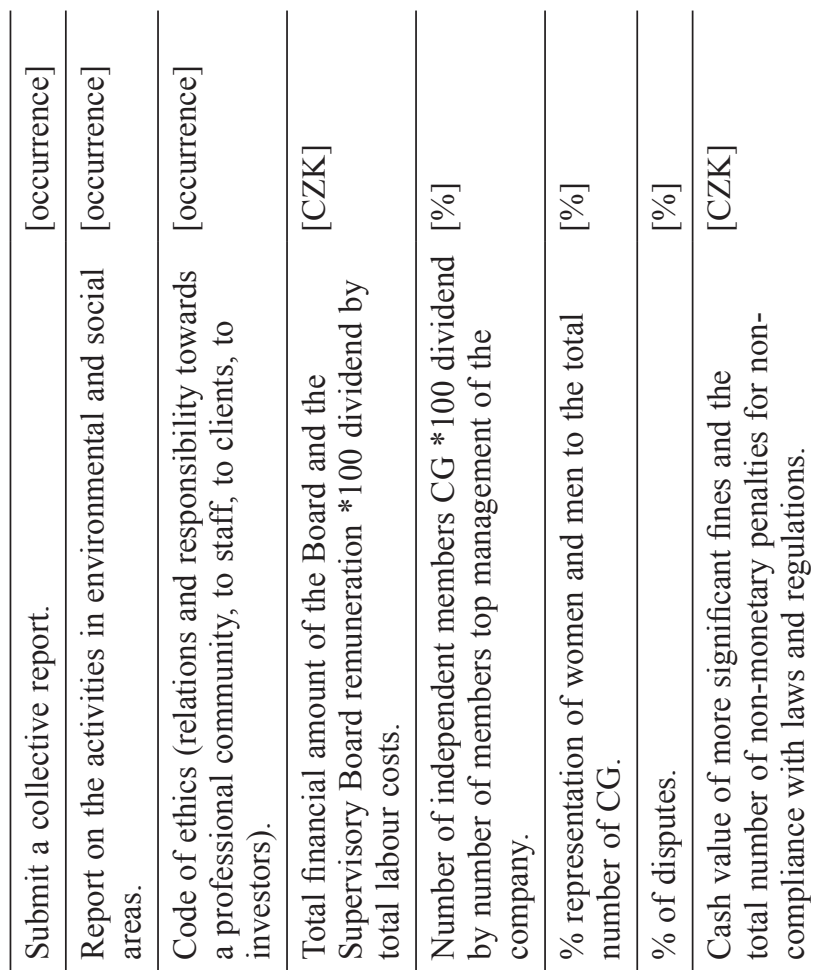

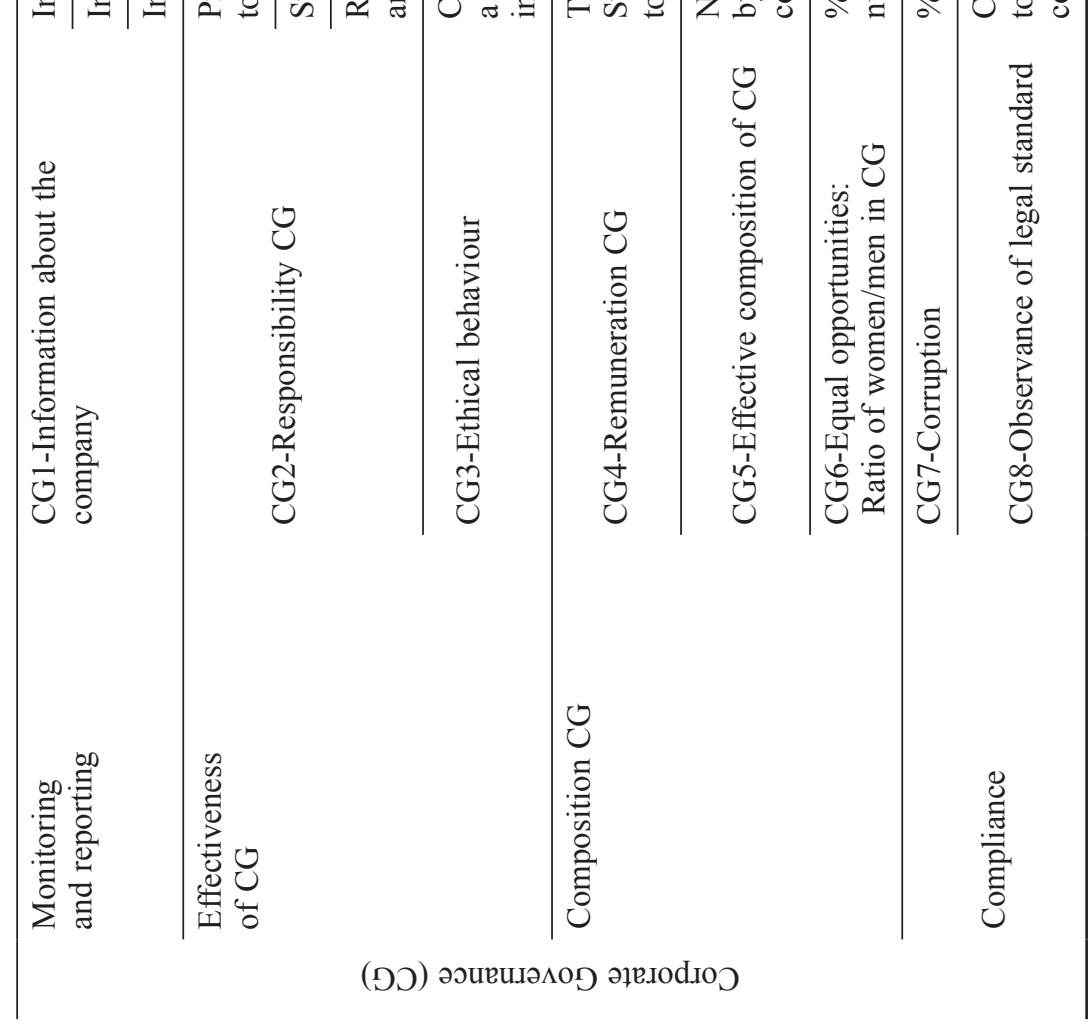


The framework for measurement of sustainable performance should assist the companies in selecting the indicators, based on their importance and significance from the point of the corporate strategy; these indicators of performance should help to show the corporate progress towards the objectives of sustainability and to ensure that they cover their environmental, social and economic impacts. Before the company decides the key indicators of performance, it must understand how to utilize them best of all, how to incorporate them into the internal management and how can they assist in and support the Sustainability reporting.

\section{Acknowledgement}

The paper is supported by The Czech Science Foundation. Name of the Project: Construction of Methods for Multifactor Assessment of Company complex Performance in Selected Sectors. Reg. Nr. P403/11/2085. Name of the Project: Measuring Corporate Sustainability in Selected Sectors. Reg. No. 14-23079S.

\section{References}

Baker, H. K.; Anderson, R. 2010. Corporate governance: a synthesis of theory, research, and practice. 1st ed. New Jersey: John Wiley \& Sons. 676 p. ISBN 9780470499139.

http://dx.doi.org/10.1002/9781118258439

Bansal, P. 2005. Evolving sustainability: a longitudinal study of corporate sustainable development, Strategic Management Journal 26(3): 197-218. http://dx.doi.org/10.1002/smj.441

Bassen, A.; Kovacs, A. M. 2008. Environmental, social and governance key performance indicators from a capital market perspective, Zeitschrift für Wirtschafts und Unternehmensethik 9(2): 182-192.

Berle, A. A.; Means, G. C. 1933. The modern corporation and private property. 1st ed. New York: Macmillan. 380 p. ISBN 0-88738-887-6.

Berrone, P.; Gomez-Mejia, L. R. 2009. Environmental performance and executive compensation: an integrated agency-institutional perspective, Academy of Management Journal 52(1): 103-126. http://dx.doi.org/10.5465/AMJ.2009.36461950

Busco, C.; Frigo, M. L.; Riccaboni, A.; Quattrone, P. 2013. Integrated reporting: concepts and cases that redefine corporate accountability. Heidelberg: Springer. 364 p. ISBN 978-3-319-02167-6.

CFA. 2012. Institute, Environmental, Social, and Governance Factors at Listed Companies: a Manual for Investors [online], [cited 12 August 2012]. Available from Internet:

http://www.cfapubs.org/toc/ccb/2008/2008/2

Demb, A.; Neubauer, F. F. 1992. The corporate board-confronting paradoxes. 1st ed. New York: Oxford University Press, Inc. 208 p. ISBN 0195070399.

EFFAS. 2008. KPIs for ESG. Key performance indicators for environmental, social and governance issues, DVFA Financial Papers No. 8/08e. Dreieich. 41 p. ISBN 978-3-928759-10-6.

Frost, R. 2010. ISO 26000 Putting Social Responsibility to Work [online], [cited 20 February 2012]. Available from Internet:

http://www.questia.com/library/1P3-2193255631/iso-26000-putting-social-responsibility-to-work GRI. 2006. About Sustainability Reporting [online], [cited 26 February 2012]. Available from Internet: https:/www.globalreporting.org/information/sustainabilityreporting/Pages/default.aspx 
GRI. 2011. G3.1 Guidelines [online] [cited 24 March 2012]. Available from Internet: http://www.globalreporting.org/ReportingFramework/G31Guidelines/

GRI. 2013. About Sustainability Reporting [online] [cited 26 March 2013]. Available from Internet: http:/www.globalreporting.org/information/sustainability-reporting/Pages/default.aspx

Garz, H.; Schnella, F 2009. KPIs for ESG. Key Performance Indicators for Environmental, Social and Governance Issues [online], [cited 24 March 2012]. Available from Internet:

http://www.rwe.com/web/cms/mediablob/en/405444/data/0/7/DVFA-criteria-for-non-financials.pdf

Ginevičius, R.; Vaitkūnaite, V. 2006. Analysis of organizational culture dimensions impacting performance, Journal of Business Economics and Management 7(4): 201-211.

http://dx.doi.org/10.1080/16111699.2006.9636141

Gourevitch, P. A.; Shinn, J. 2005. Political power and corporate control: the new global politics of corporate governance. 1st ed. Princeton University Press. 368 p. ISBN 9780691133812.

Green Paper on the EU Corporate Governance Framework. 2011. [Online], [cited 12 March 2011]. Clifford Chance. Available from Internet:

http://www.cliffordchance.com/publicationviews/publications/2011/04/green_paper_on_theeucorporategovernanc.html

Greenwald, Ch. 2007. The importance of consistent and comparable ESG performance data [online], [cited 21 September 2012]. Available from Internet:

http://www.asset4.com/pdf/ASSET4-The-importance-of-consistent-and-comparable-ESG-performance-data.pdf

IFAC. 2012. Investor Demand for Environmental, Social and Governance Disclosures [online], [cited 8 July 2012]. Available from Internet:

http://www.ifac.org/publications-resources/investor-demand-environmental-social-and-governance-disclosures

Jacobsen, J. 2011. The quality professional's role in ISO 26000, Journal for Quality \& Participation 34(1): 21-24.

Hair, J. F.; Black, W. C.; Babin, B. E.; Anderson R. E.; Tatham, R. L. 2006. Study guide for multivariate data analysis by Hair. 6th ed. Upper Saddle River: Pearson Prentice Hall. 116p. ISBN 9780138948580.

Harts, S. 1995. A natural resource-based view of the firm, Academy of Management Review 20(4): 966-1014.

Hope, J.; Fraser, R. 2003. Who needs budgets, Harvard Business Review 81(2): 108-115.

Hosseini, S. J. F.; Mohammadib, F.; Mirdamadia, S. M. 2010. Factors influencing the economic aspects of sustainable agriculture in Iran, African Journal of Agricultural Research 6(2): 451-457.

Kaplan, R. S.; Norton, D. P. 1996. The balanced scorecard: translating strategy into action. USA: Harvard Business School Press. 267p. ISBN 0-87584-651-3.

Kocmanová, A.; Šimberová, I. 2012. Modelling of corporate governance performance indicators, Engineering Economics 23(5): 485-495. http://dx.doi.org/10.5755/j01.ee.23.5.2865

Kocmanová, A.; Dohnal, M.; Meluzin, T. 2011. Qualitative simple equation less models as simple integrators of vague sustainability knowledge items, Transformations in Business \& Economics 11(3): 187-196.

Kruse, C.; Lundgergh, S. 2010. The governance of corporate sustainability, Rotman International Journal of Pension Management 20(2): 46-51. http://dx.doi.org/10.3138/rijpm.3.2.46

Loska, T. 2013. Integrated reporting. GRIN Verlag. 88 p. ISBN 978-3-656-08866-0.

Monks, R. A. G.; Minow, N. 2011. Corporate governance. 5th ed. Chichester: John Wiley \& Sons. 489 p. ISBN 978-0-470-97259-5. 
Neely, A.; Gregory, M.; Platts, K. 1995. Performance measurement system design: a literature review and research agenda, International Journal of Operations \& Production Management 15(4): 80-116. http://dx.doi.org/10.1108/01443570310458465

Neely, A.; Kennerley, M. 2003. Measuring performance in a changing business environment, International Journal of Operations \& Production Management 23(2): 213-229. http://dx.doi.org/10.1108/01443570310458465

Neely, A.; Adams, C. 2001. The performance prism perspective, Journal of Cost Management 15(1):7-15. http://dx.doi.org/10.1108/13683040110385142

OECD. 2004. Principles of Corporate Governance [online], [cited 1 February 2012]. Available from Internet: http://www.oecd.org/dataoecd/32/18/31557724.pdf

Ommani, A. R. 2011. Favorable content of sustainable agriculture extension programs in Khuzestan province of Iran, Applied Science Research 3(2): 503-512.

Parmenter, D. 2007. Key performance indicators: developing, implementing and using winning KPIs. New Jersey: Hohn Wiley \& Sons. 256 p.

Petrosyan, A. 2010. A model for incorporated measurement of sustainable development comprising remote sensing data and using the concept of biodiversity, Journal of Sustainable Development 3(2): 9-26. http://dx.doi.org/10.5539/jsd.v3n2p9

Ribando, J. M.; Bonne, G. 2010. A new quality factor: finding alpha with Asset4 ESG Data. New York: Thomson Reuters.

Russo, M. V.; Harrison, N. S. 2005. Organizational design and environmental performance: clues from the electronics industry, Academy of Management Journal 48(4): 582-593.

http://dx.doi.org/10.5465/AMJ.2005.17843939

Saisana, M.; Tarantola, S.; Saltelli, A. 2005. Uncertainty and sensitivity techniques as tools for the analysis and validation of composite indicators, Journal of the Royal Statistical Society A 168(2): 307-323. http://dx.doi.org/10.1111/j.1467-985X.2005.00350.x

Sharma, S.; Henriques, I. 2005. Stakeholder influences on sustainability practices in the Canadian forest products industry, Strategic Management Journal 26(2): 159-180.

http://dx.doi.org/10.1002/smj.439

Singh, R. K; Murty, H. R.; Gupta, S. K.; Dikshit, A. K. 2007. Development of composite sustainability performance index for steel, Journal of Ecological Indicators 7: 565-588.

http://dx.doi.org/10.1016/j.ecolind.2006.06.004

Spirig, K. 2006. Social performance and competitiveness, a socio-competitive framework, in S. Schaltegger, M. Wagner (Eds.). Managing the business case for sustainability. Sheffield, UK: Greenleaf, 82-106. http://dx.doi.org/10.1016/j.ecolind.2006.06.004

UNCTAD/TDR. 2008. Trade and Development Report, Commodity Prices, Capital Flows and the Financing of Investment [online], [cited 8 July 2011]. Available from Internet:

http://www.un-ngls.org/spip.php?page=article_s\&id_article $=565$

Vermunt, J. K. 2008. Multilevel latent variable modelling: an application in educational testing, Austrian Journal of Statistics 37(3-4): 285-299.

Vermunt, J. K.; Magidson, J. 2005. Factor analysis with categorical indicators: a comparison between traditional and latent class approaches, in A. van der Ark, M. A. Croon, K. Sijtsma (Eds.). New developments in categorical data analysis for the social and behavioral sciences. Mahwah: Erlbaum, 41-62. 
Alena KOCMANOVÁ is an Associate Professor in Corporate Economics, Cost Management, Environmental Management, and since 2012, she has combined this role with position of the vice-dean for Development at Faculty of Business and Management, Brno University of Technology. Her research interests in corporate performance environmental, social, economic and corporate governance, managerial accounting, cost accounting, environmental management, company economics and management. She takes part in resolving grant projects and international projects

Iveta ŠIMBEROVÁ is an Associate Professor in Marketing Management and Commerce, and since 2012, she has combined this role with position of the vice-dean for International Relationship at Faculty of Business and Management, Brno University of Technology. Her research interests in corporate governance indicators, modern marketing concepts including stakeholder marketing management, total customer satisfaction, marketing culture and the internationalisation of small and medium enterprises. She worked as coordinator of several international projects and grants. 